Journal of Food Technology 9 (3): 99-105, 2011

ISSN: $1684-8462$

(C) Medwell Journals, 2011

\title{
Comparison Between Ordinary and Dark Muscle Extracts of Yellowtail (Serila quinqueradiata) on Chemical Characteristics, Antiproliferative and Antioxidant Properties
}

\author{
${ }^{1}$ J.H. Bae, ${ }^{2}$ S. Y. Hwang, ${ }^{3}$ S.H. Yoon, ${ }^{2}$ I. Noh and ${ }^{2}$ S. Y. Lim \\ ${ }^{1}$ National Fisheries Products Quality Inspection Service, Busan, Korea \\ ${ }^{2}$ Division of Marine Environment and Bioscience, Korea Maritime University, Busan, Korea \\ ${ }^{3}$ Department of Food Science and Biotechnology, Kyungsung University, Busan, Korea
}

\begin{abstract}
Chemical characteristics of ordinary and dark muscles from yellowtail and effects of extracts from both muscles on cancer cell proliferation and antioxidant were investigated. Ordinary muscles showed significantly higher contents of moisture, crude protein and ash with lower crude fat compared to dark muscles. There were significant differences in the percentages of total saturated, monounsaturated and polyunsaturated fatty acids. Inhibition of AGS cell proliferation was highest with the treatment of $1.0 \mathrm{mg} \mathrm{mL}^{-1}$ acetone/methylene chloride extract of dark muscles. Extracts of ordinary muscles induced weak inhibitory effect on the proliferation of HT-29 cell line. In addition, the extracts of ordinary and dark muscles decreased cellular Reactive Oxygen Species (ROS) of HT-1018 cells in comparison to the control cells. Thus, the data suggested that yellowtail muscle may have beneficial effects on cancer development and cellular oxidation and particularly dark muscles have higher inhibitory effect on growth of cancer cells.
\end{abstract}

Key words: Muscle type, fatty acid composition, antiproliferation, antioxidant, cellular oxidation, ROS

\section{INTRODUCTION}

Fish is a good source of highly nutritive proteins, lipids, vitamins and minerals. It has high protein with low saturated fat and provides many beneficial effects. In general, all fishes are known to have rich sources of n-3 Polyunsaturated Fatty Acids (PUFA) and most marine lipids are good sources of Eicosapentaenoic Acid (EPA, 20:5 n-3) and Docosahexaenoic Acid (DHA, 22:6n-3). The consumption of fish oil can prevent many cardiovascular diseases. PUFA play an important role in the prevention and treatment of diseases like hypertenstion, atherosclerosis and some cancers. At the other hand, they improve learning ability and the development of mammalian brain (Yonekubo et al., 1994; Suzuki et al., 1998; Harrocks and Yeo, 1999; Nordov et al., 2001). Fish muscles are composed of ordinary (white skeletal) and dark (red skeletal) muscles. Ordinary muscles are used only for sudden movements, despite their large volume in the body. In contrast, the dark muscles line mostly along the lateral line of fish and are used for constant cruising at low speed (Tsukamoto, 1984). Dark muscles in general are more prone to lipid oxidation than the ordinary muscles (Shahidi and Spurvy, 1996). This is probably not only because dark muscles have higher lipid contents but the fact that they also contains higher amounts of pro-oxidant metals (Decker and Hultin, 1990). Typically, the volume of dark muscles to ordinary muscles varies from $1-30 \%$ depending on fish species. Mackerel and sardine fishes have high contents of dark muscles and are reported to have high contents of lipid, myoglobin, alkali soluble protein, stroma and glucogen (Chaijan et al., 2004). Interestingly, fish species with dark muscles currently make up $40-50 \%$ of the total fish catch in the world (Hultin and Kelleher, 2000). Recently, the beneficial effects of dark muscles of fishes are gaining more and more attention, not only for the food aspects but also for the development of potential pharmaceuticals. In recent years, it has been reported that gel-forming ability and surimi processing technology from dark muscles have achieved a significant impetus (Kelleher et al., 1994; Hultin and Kelleher, 2000; Ochiai et al., 2001; Chaijan et al., 2010).

Yellowtail (Serila quinqueradiata) belongs to the Carangidae family of fishes and is one of the most important commercial species. The dark muscles of yellowtail are considered to be a delicacy and widely eaten raw in Japan and Korea. The presence of a large number of essential amino acids makes yellowtail muscle an excellent unique source for nutrients and easily digestible protein (NFRDI, 2009). It is found in the Atlantic, Indian and Pacific oceans and may weigh up to $15 \mathrm{~kg}$. Catches of yellowtail in Korea reached 5,321 ton in 2004 since then they have been increasing to a maximum

Corresponding Author: S.Y. Lim, Division of Marine Environment and Bioscience, Korea Maritime University, Busan, Korea 
of 12,643 ton in 2008 (MFAFF, 2009). Production of cultured yellowtail in Japan (Seriola sp.) reached their 150,028 ton in 2004 (Nakada, 2008). Previous studies have suggested that chemical composition of fish muscle are known to vary with the anatomical location of the muscle (Thakur et al., 2002, 2003; Testi et al., 2006; Mohan et al., 2008; Bae et al., 2010). So far there are no studies on chemical characteristics and biological activities of ordinary and dark muscle extracts from yellowtail. The objective of the present study was to compare the chemical characteristics of ordinary and dark muscles from yellowtail and to examine the inhibitory effects of both muscle extracts on cell proliferation and their antioxidant properties.

\section{MATERIALS AND METHODS}

Materials and cell culture: Dulbeco's Modified Eagle's Medium (DMEM), Fetal Bovine Serum (FBS), Phosphate Buffer Saline (PBS), Dimethylsulfoxide (DMSO), penicilline-strectomycine, 3-(4, 5-dimethylthiazol-2-yl)-2,5diphenyltetrazolium bromide (MTT) and 2-7' Dichlorofluorescein-Diacetate (DCFH-DA) were obtained from Sigma-Aldrich (St. Louis, USA). AGS human gastric cancer, HT-29 human colon cancer and HT-1080 human fibroblast cell lines were obtained from the Korea Cell Line bank. The cells were grown in DMEM containing $10 \%$ FBS and 100 units $\mathrm{mL}^{-1}$ penicillin-streptomycin and maintained at $37^{\circ} \mathrm{C}$ under $5 \% \mathrm{CO}_{2}$.

Samples and extraction: Yellowtail was purchased in the Jagalchi fish market of Korea. Yellowtail was gutted, eviscerated and filleted on two sides. The ordinary and dark muscles were carefully excised from each fillet and used for measuring the proximate and fatty acid compositions. The ordinary and dark muscles of yellowtail were sequentially extracted twice with acetone/methylene chloride $(\mathrm{A}+\mathrm{M})$ and Methanol $(\mathrm{MeOH})$. The extracts were evaporated to dryness using a rotary vacuum evaporator (N-1000VW, EYELA, Tokyo, Japan) with the water bath heated at $40^{\circ} \mathrm{C}$. The same extract was used in many cancer cells to study the antiproliferatory and antioxidant effects.

Analysis of proximate composition: Moisture content was determined by drying sample in an oven at $105^{\circ} \mathrm{C}$ until constant weight was obtained. Crude fat was determined by using the Soxhlet extraction method. Crude protein content was determined by the Kjeldahl nitrogen using a 6.25 conversion factor. Ash was determined by incineration in a muffle furnace at $550^{\circ} \mathrm{C}$ for $24 \mathrm{~h}$ (KSFSN, 2000).

Measurement of fatty acid composition: Sample lipids were extracted with chloroform-methanol (2:1 v/v) according to the method of Bligh and Dyer (1959). The mixture was filtered through filter paper and the filtrate was transferred to a separatory funnel. The chloroform layer was collected and concentrated by a rotary evaporator. Fatty acid methyl esters were prepared by $14 \% \mathrm{BF}_{3} /$ methanol. Fatty acid methyl esters were analyzed by gas chromatography (CP-3380, Varian, Santa Clara, USA) with a flame-ionization detector as described previously (Salem et al., 1996). The chromatography utilized an $\mathrm{SP}^{\mathrm{TM}}-2560$ fused silica capillary column $(100 \times 0.25 \mathrm{~mm}$ i.d.). Peaks were identified by comparison with fatty acid standards (GLC-462, Nu-Check-Prep, Elysian, USA). Area and its percentage for each resolved peak were analyzed using a Galaxie software.

Inhibition of cancer cell proliferation: The cell viability was determined by using MTT assay (Denizot and Lang, 1986). Briefly, cells were seeded in 96-well plates at a density of $5 \times 10^{3}$ cells/well. After incubating for $24 \mathrm{~h}$, the cells were treated with different concentrations of samples. After incubation for $48 \mathrm{~h}$, the cells were incubated with $100 \mu \mathrm{L}$ of MTT $\left(1 \mathrm{mg} \mathrm{mL}^{-1}\right)$ for $4 \mathrm{~h}$. Finally the medium was removed and $100 \mu \mathrm{L}$ of Dimethylsulfoxide (DMSO) were added to solubilize the formed formazan crystals. The amount of formazan crystal was determined by measuring the absorbance at $540 \mathrm{~nm}$ using a microplate spectrophotometer (VICTOR3, Perkin Elmer, Waltham, USA). The percent inhibition of cell proliferation was calculated as follows:

$$
\text { Inhibitation }(\%)=\frac{\left(\begin{array}{l}
\text { Abs. } 540 \mathrm{~nm} \text { control }- \\
\text { Abs.540 nm sample }
\end{array}\right)}{\text { Abs. } 540 \mathrm{~nm} \text { control }} \times 100
$$

Measurement of intracellular Reactive Oxygen Species (ROS): Cellular oxidative stress owing to ROS generation from $\mathrm{H}_{2} \mathrm{O}_{2}$ was measured by the DCFH-DA method (LeBel et al., 1992). In principle, DCFH-DA that diffuses through the cell membranes is enzymatically hydrolyzed by intracellular esterase to the non fluorescent DCFH which can be rapidly oxidized to the highly fluorescent DCF in the presence of ROS. HT-1080 cells were first cultured in 96 well plates $\left(5 \times 10^{5} /\right.$ well) for $24 \mathrm{~h}$. After washing with PBS, cells were pre-incubated with $20 \mu \mathrm{M}$ DCFH-DA for $20 \mathrm{~min}$. Then, the samples were treated and incubated for $1 \mathrm{~h}$. After DCFH-DA was removed and washed with $\mathrm{PBS}, 500 \mu \mathrm{M} \mathrm{H}_{2} \mathrm{O}_{2}$ were added and incubated for $120 \mathrm{~min}$. DCF fluorescence intensity was measured with an excitation wavelength at $485 \mathrm{~nm}$ and emission wavelength at $535 \mathrm{~nm}$ using fluorometric plate reader (VICTRO3, Perkin Elmer, Waltham, USA).

Statistical analysis: Data were presented as mean \pm standard deviation. Analytical data were subjected to one-way Analysis of Variance (One-Way ANOVA) followed by Duncan's multiple range test for differences 
among different treatment concentrations. Significant differences of ordinary and dark muscle were tested using the independent samples t-test. Analyses were conducted using SPSS Version 10.0 software package. Significant $(\mathrm{p}<0.05)$ differences are shown by different superscript letters in the tables.

\section{RESULTS AND DISCUSSION}

Comparison between ordinary and dark muscles on proximate composition: Proximate composition is a good indicator of the physiological condition of a fish but it is relatively time consuming to measure. There were significant differences in proximate composition of ordinary muscles in comparison to dark muscles (Table 1). Ordinary muscle showed significantly higher contents of moisture, crude protein and ash and lower contents of crude fat compared to dark muscle $(\mathrm{p}<0.05)$. Proximate composition of yellowtail captured in May has been regarded to have $75.6 \%$ moisture, $0.8 \%$ crude fat, $21.7 \%$ crude protein and $1.5 \%$ ash (NFRDI, 2009).

It is known that variations in the proximate composition of marine fishes are closely related to nutrition, living area, fish size, catching season, seasona and sexual variations as well as other environmental condition (Kitts et al., 2004; Erkan and Ozden, 2007). Proximate composition of yellowtail varied with anatomical location and a large variation was observed in muscle lipid content which decreased significantly from head to tail (Thakur et al., 2002). Dark muscle contained almost three times as much total lipid as ordinary muscle in herring (Clupea harengus) (Undeland et al., 1998). The stroma protein and myoglobin contents were around 5 and 10-40 times, respectively higher in the dark than in the ordinary muscle in tuna fish (Kanoh et al., 1986). Bae et al. (2010) reported that in chub and blue mackerel, the contents of moisture, crude protein and ash in dark muscle were lower than ordinary muscle. The present study demonstrated a similar result that ordinary muscle had higher contents of moisture, crude protein and ash with lower crude fat. Zlatanos and Laskaridis (2007) reported that fat and fatty acid contents of three common Mediterranean fish (sardine, anchovy and picarel) showed significant seasonal dependency. The chemical characteristics of dark and ordinary muscles differ with dark muscle having higher fat, myoglobin and glucogen contents. A different influence of seasonality on the various kinds of fish from

Table 1: Proximate composition (\%) between ordinary and dark muscles \begin{tabular}{lll}
\multicolumn{2}{c}{ from yellowtail } & \\
\hline Composition & Ordinary muscle & Dark muscle \\
\hline
\end{tabular} $\begin{array}{lcc}\text { Moisture } & 70.6 \pm 0.5 & 67.5 \pm 0.4^{*}\end{array}$ $\begin{array}{lrr}\text { Crude fat } & 3.2 \pm 0.8 & 8.2 \pm 0.9^{*}\end{array}$

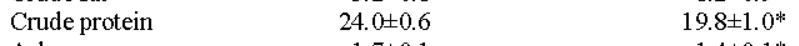
\begin{tabular}{lrr} 
Ash & $1.7 \pm 0.1$ & $1.4 \pm 0.1^{*}$ \\
\hline
\end{tabular} Data were presented as mean \pm standard deviation $(n=3) ; * p<0.05$ significantly different as compared to ordinary muscle the same geographic area is common and is probably affected by the different genetic cycle of fish species (Luzia et al., 2003).

Comparison between ordinary and dark muscles on fatty acid composition: The fatty acid profile of fish muscles tends to reflect the profile in the diet but the extent to which this occurs can depend on many factors such as concentration and profile of fatty acids in feed, species of fish, specific muscle, lipid class isolated and physiological state. Comparison of fatty acid composition detected obvious differences between ordinary and dark muscles (Table 2). There were significant differences in the percentages of total Saturated Fatty Acids (SFA), Monounsaturated Fatty Acids (MUFA) and PUFA $(\mathrm{p}<0.05)$. The ordinary muscle showed higher levels of 22:6n-3 compared to dark muscle. The notable differences were slightly lesser but significantly lower levels of 20:0, 20:1 n-9 and 18:3 n-3 in dark muscle in comparison to ordinary muscle $(\mathrm{p}<0.05)$. The main SFAs were palmitic acid (16:0), stearic acid (18:0), the main MUFA and PUFA were oleic acid (18:1 n-9) and docosahexaenoic acid (22:6n-3), respectively. The fatty acid composition is the most important chemical compounds of all the fishes. The ingestion of PUFA is very important for human health. The predominant fatty acids of various fish species were $16: 0,16: 1 \mathrm{n}-7,18: 1 \mathrm{n}-9,20: 5 \mathrm{n}-3$ and $22: 6 \mathrm{n}-3$ in both ordinary and dark muscles (Sohn et al., 2005). The levels of PUFA, including 20:5 n-3 and 22:6n-3 were higher in the dark muscle compared to the ordinary muscle in chub mackerel and skipjack tuna (Bae et al., 2010; Sohn and Ohshima, 2010). In the present study, dark muscle contained lower percentage of PUFA with higher percentage of SFA and MUFA. The levels of PUFA

Table 2: Fatty acid composition (area\%) between ordinary and dark muscles from yellowtail

\begin{tabular}{lcc}
\hline Composition & Ordinary muscle & Dark muscle \\
\hline $14: 0$ & $4.2 \pm 0.3$ & $4.8 \pm 0.0^{*}$ \\
$16: 0$ & $23.2 \pm 0.5$ & $23.7 \pm 0.7$ \\
$18: 0$ & $6.0 \pm 0.2$ & $6.9 \pm 0.3^{*}$ \\
$20: 0$ & $1.7 \pm 0.0$ & $0.5 \pm 0.0^{*}$ \\
$22: 0$ & $\mathrm{ND}$ & $0.3 \pm 0.0$ \\
$24: 0$ & $\mathrm{ND}$ & $0.2 \pm 0.1$ \\
Total SFA & $35.1 \pm 0.3$ & $36.5 \pm 0.6^{*}$ \\
$16: 1 n-7$ & $7.0 \pm 0.2$ & $7.7 \pm 0.5$ \\
$18: 1 n-9$ & $17.6 \pm 0.4$ & $18.7 \pm 0.5$ \\
$18: 1 n-7$ & $3.3 \pm 0.5$ & $4.4 \pm 0.1$ \\
$20: 1 n-9$ & $0.5 \pm 0.4$ & $0.2 \pm 0.0^{*}$ \\
$24: 1 n-9$ & $\mathrm{ND}$ & $0.5 \pm 0.1$ \\
Total MUFA & $28.4 \pm 0.4$ & $31.4 \pm 1.0^{*}$ \\
$18: 2 n-6$ & $1.1 \pm 0.1$ & $1.3 \pm 1.0$ \\
$18: 3 n-3$ & $1.0 \pm 0.1$ & $0.1 \pm 0.0^{*}$ \\
$20: 4 n-6$ & $\mathrm{ND}$ & $1.7 \pm 0.3$ \\
$20: 5 n-3$ & $10.7 \pm 0.6$ & $9.2 \pm 0.2^{*}$ \\
$22: 5 n-3$ & $2.5 \pm 0.2$ & $2.7 \pm 0.2$ \\
$22: 6 n-3$ & $21.2 \pm 0.2$ & $17.1 \pm 1.0^{*}$ \\
Total PUFA & $36.5 \pm 0.5$ & $32.1 \pm 0.7^{*}$ \\
\hline Data were presented as mean \pm standard deviation (n $=3$ ); SFA: Saturated \\
Fatty Acids; MUFA: Monounsaturated Fatty Acids; PUFA: Polyunsaturated \\
Fatty Acids; ND: Not Detected; * $<0.05$ significantly different as compared \\
to ordinary muscle & & \\
& &
\end{tabular}


including 20:5n-3 and 22:6n-3 were markedly higher in the ordinary muscle compared with the dark muscle. However, Undeland et al. (1998) suggested that fatty acid patterns of herring did not detect any significant differences between the ordinary and dark muscles. As reported by others, the fatty acid composition and lipid contents of fishes does get affected by the species, sex, age, water temperature, degree of pollution, nutritional condition, seasonal variation and fish origin (Tanakol et al., 1999; Bandarra et al., 2001).

Inhibition of cell proliferation: The widely used MTT assay that is used to the mitochondrial activity has shown considerable decrease in activity which in turn may reflect a decrease in cell proliferation or viability. Figure 1 and 2 showed inhibitory effects on the proliferation of human cancer cell lines (AGS gastric and HT-29 colon) by

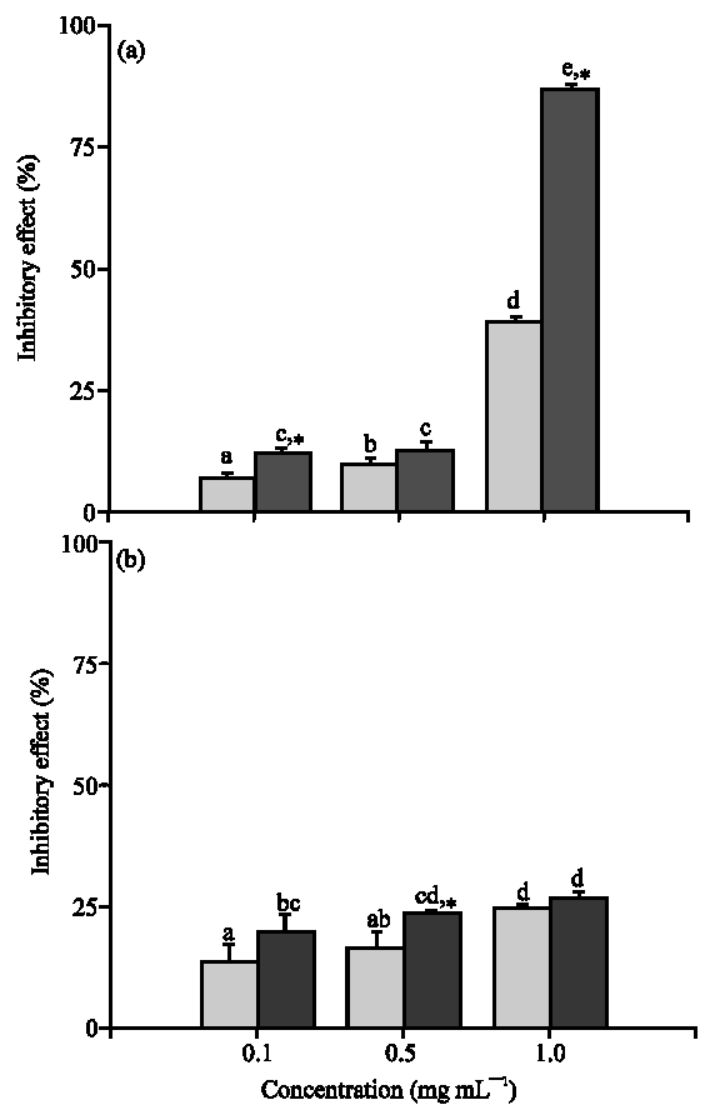

Fig. 1: Inhibitory effect of extracts of ordinary and dark muscles from yellowtail on the proliferation of AGS human gastric cancer cell lines; a) Acetone/ Methylene chloride (A+M) fraction; b) Methanol fraction; $\square$, ordinary muscle; $\mathbf{\square}$, dark muscle; ${ }^{\text {a-e }}$ indicates a significant difference $(p<0.05)$ among groups with various concentrations; ${ }^{*} \mathrm{p}<0.05$ significantly different as compared to ordinary muscle extracts of ordinary and dark muscles from yellowtail. $\mathrm{A}+\mathrm{M}$ extract of ordinary and dark muscles dosedependently decreased the growth of AGS cells. Inhibition of AGS cell proliferation was greatest with the $1.0 \mathrm{mg} \mathrm{mL}^{-1} \mathrm{~A}+\mathrm{M}$ extract treatment of dark muscles and IC50 was $0.67 \mathrm{mg} \mathrm{mL}^{-1}$ (Fig. 1).

Methanol extracts of ordinary and dark muscles induced weak inhibitory effect on the proliferation of AGS cells. There were markedly significant differences in HT-29 cell proliferation between extracts of ordinary and dark muscles. Extracts of ordinary muscles induced weak inhibitory effect on the proliferation of HT-29 cells (Fig. 2). Extracts of dark muscles inhibited HT-29 cell proliferation in a dose-dependent treatment during the $72 \mathrm{~h}$ incubation period. IC50 of A+M and methanol extracts were 0.82 and $0.89 \mathrm{mg} \mathrm{mL}^{-1}$, respectively. Jang et al. (2008) suggested that $\mathrm{A}+\mathrm{M}$ extracts from chub mackerel dose-
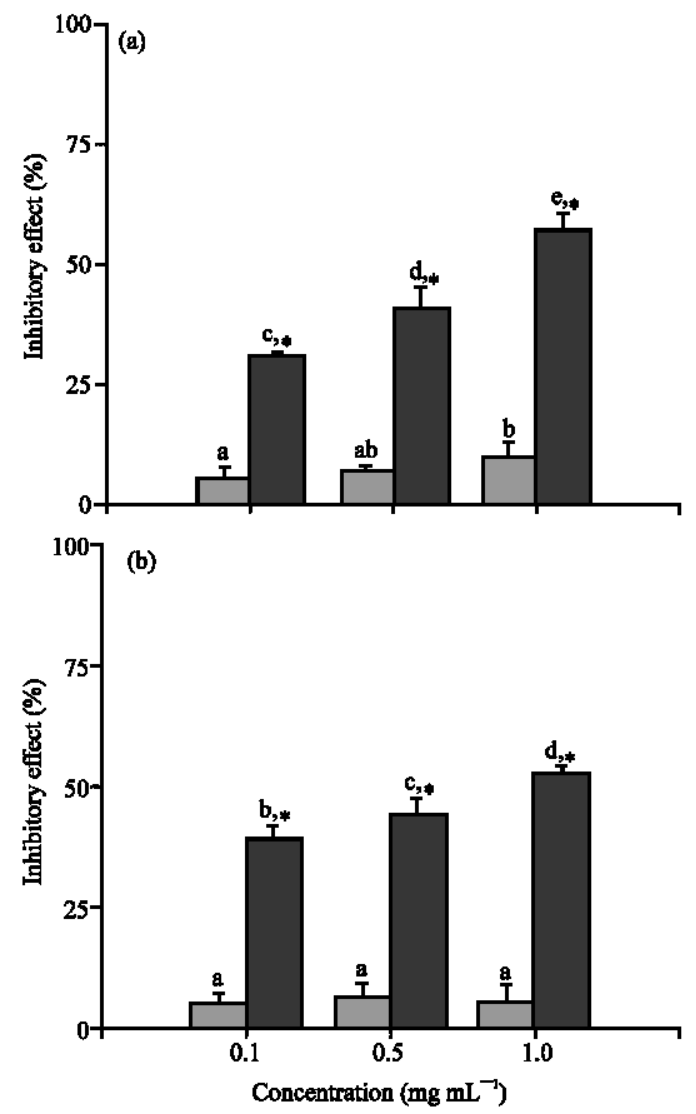

Fig. 2: Inhibitory effect of extracts of ordinary and dark muscles from yellowtail on the proliferation of HT-29 human colon cancer cell lines; a) Acetone/Methylene chloride $(\mathrm{A}+\mathrm{M})$ fraction; b) methanol fraction; $\square$, ordinary muscle; $\mathbf{\square}$, dark muscle; a-eindicates a significant difference $(\mathrm{p}<0.05)$ among groups with various concentrations; ${ }^{*} \mathrm{p}<0.05$ significantly different as compared to ordinary muscle 
dependently inhibited the proliferation of HT-29 cells. Methanol extracts of kelps and red algae exhibited dose-dependent inhibition of the growth of AGS and HT-29 colon cancer cells (Cho et al., 1997). Similarly, salivary gland extracts of octopus (Octopus ageina) showed that growth of COLO 205 cells were inhibited effectively and $\beta$-glucuronidase and mucinase activity were reduced considerably. This decrease in cell growth might be due to cell cycle inhibition or inhibiting DNA (Karthigayan et al., 2006). Glycolipids from cyanobacteria contained three potent biologically active molecules concerning their ability to induce the aggregation of washed rabbit platelets or to antagonize the actions of platelet-activating factor. All three molecules were phosphoglycolipids, two of them having a sphingosine backbone while the other one had a phosphatidylglycerol backbone (Antonopoulou et al., 2005).

Antioxidant effect: Inhibitory effect of extracts in ordinary and dark muscles on $\mathrm{H}_{2} \mathrm{O}_{2}$ induced ROS production in HT-1080 cells was shown in Fig. 3. Extracts of ordinary and dark muscles decreased the production of ROS induced by $\mathrm{H}_{2} \mathrm{O}_{2}$ compared to the control cells during $120 \mathrm{~min}$ and there was no difference between ordinary and dark muscles.

These results indicate that extracts from yellowtail muscle are thought to have an antioxidative activity based on its protective effect against the levels of intracellular ROS. Jang et al. (2008) suggested that solvent fractions (n-hexane, 85\% aqueous methanol, n-butanol and

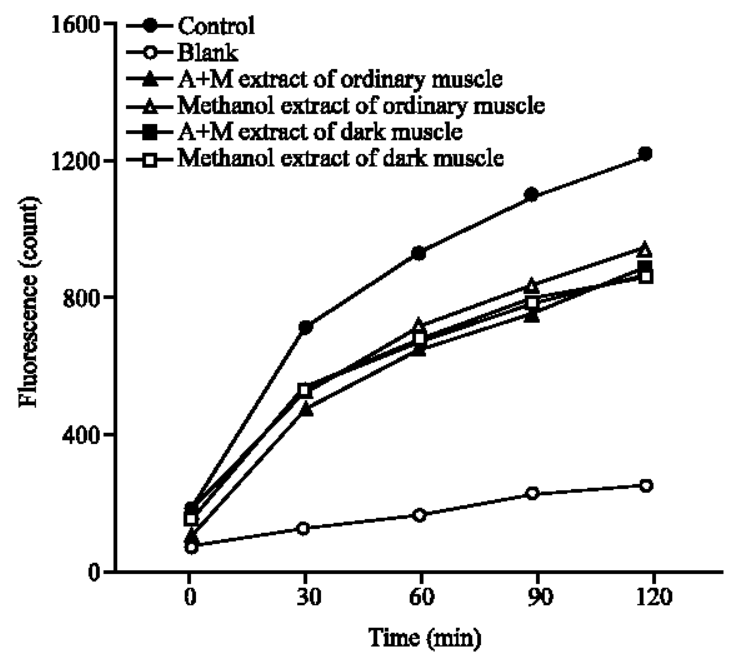

Fig. 3: Inhibitory effect of extracts of ordinary and dark muscles $\left(0.01 \mathrm{mg} \mathrm{mL} \mathrm{mL}^{-1}\right.$ concentration) from yellowtail on levels of reactive oxygen species in HT-1080 cell lines. Control, sample was treated with $500 \mu \mathrm{m} \mathrm{H}_{2} \mathrm{O}_{2}$ and phosphate buffered saline; blank, sample was treated with phosphate buffered saline without $\mathrm{H}_{2} \mathrm{O}_{2}$ water) from chub mackerel inhibited the production of ROS and that $85 \%$ aqueous methanol fraction among them had a strong effect on reducing ROS. They also suggested that $85 \%$ aqueous methanol fraction of dried tuna, another fish with blue color on the back had a protective effect on production of lipid peroxides (Jang et al., 2009). The above fish (mackerel, tuna and yellowtail) contain high levels of n-3 PUFAs. N-3 PUFAs such as EPA and DHA are hardly thought to have any antioxidative activity since, these fatty acids contain higher levels of unsaturation that are prone to oxidation. Therefore, intracellular antioxidants are thought to mediate these activity of DHA which stimulates the levels or activity of these antioxidants.

Komatsu et al. (2003) suggest that treatment with DHA causes the intracellular glutathione (GSH) enhancement and stimulates intracellular protective responses against oxidative stress. Since, dietary DHA supplementation causes increase in the activities of catalase, Glutathione Peroxidase (GPx) and GSH in brain, DHA is likely to induce the entire antioxidative defense system (Hossain et al., 1999). N-3 PUFAs markedly suppressed the production of Nitric Oxide (NO) and the expression of inducible NO Synthase (iNOS) in murine macrophages (Khair-El-Din et al., 1996; Ohata et al., 1997; Lu et al., 1998). Excessive production of NO is associated with not only acute and chronic inflammation (MacMicking et al., 1997) but also cancer development (Mordan et al., 1993; Ohshima and Bartsch, 1994).

\section{CONCLUSION}

The yellowtail is very important commercial fish in Korea since, yellowtail muscle has excellent amino acid composition, a unique source of nutrients and easily digestible protein. In this study, we have shown that yellowtail muscles have inhibitory effects on cancer development and cellular oxidation. The antiproliferatory effects of dark muscle extracts in cancer cell lines clearly suggests its potential role in treating certain types of cancers.

In addition, the present data also provide useful information to further study the chemical characteristics and biological activities of ordinary and dark muscles from yellowtail. However, further research involving use of these extracts as functional food for human administration need more investigation.

\section{ACKNOWLEDGEMENT}

This research is the outcome of a Manpower Development Program for Marine Energy by the Ministry of Land, Transport and Maritime Affairs (MLTM). 


\section{REFERENCES}

Antonopoulou, S., T. Nomikos, A. Oikonomou, A. Kyriacou, M. Andriotis, E. Fragopoulou and A. Pantazidou, 2005. Characterization of bioactive glycolipids from Scytonema julianum (cyanobacteria). Comp. Biochem. Physiol. B Biochem. Mol. Biol., 140: 219-231.

Bae, J.H., S.H. Yoon and S.Y. Lim, 2010. A comparison of the biochemical characteristics of different anatomical regions of chub (Scomber japonicus) and blue mackerel (Scomber australasicus) muscles. Kor. J. Fish. Aquat. Sci., 43: 6-11.

Bandarra, N.M., I. Batista, M.L. Nunes and J.M. Empis, 2001. Seasonal variation in the chemical composition of horse-mackerel (Trachurus trachurus). Eur. Food Res. Technol., 212: 535-539.

Bligh, E.G. and W.J. Dyer, 1959. A rapid method of total lipid extraction and purification. Can. J. Biochem. Physiol., 37: 911-917.

Chaijan, M., S. Benjakul, W. Visessanguan and C. Faustman, 2004. Characteristics and gel properties of muscles from sardine (Sardinella gibbosa) and mackerel (Rastrelliger kanagurta) caught in Thailand. Food Res. Int., 37: 1021-1030.

Chaijan, M., W. Panpipat and S. Benjakul, 2010. Physicochemical properties and gel-forming ability of surimi from three species of mackerel caught in Southern Thailand. Food Chem., 121: 85-92.

Cho, E.J., S.H. Rhee and K.Y. Park, 1997. Antimutagenic and cancer cell growth inhibitory effects of seaweeds. J. Food Sci. Nutr., 2: 348-353.

Decker, E.A. and H.O. Hultin, 1990. Factors influencing catalysis of lipid oxidation by the soluble fraction of mackerel muscle. J. Food Sci., 55: 947-950.

Denizot, F. and R. Lang, 1986. Rapid colorimetric assay for cell growth and survival. modifications to the tetrazolium dye procedure giving improved sensitivity and reliability. J. Immunol. Methods, 89: $271-277$.

Erkan, N. and O. Ozden, 2007. Proximate composition and mineral contents in aqua cultured sea bass (Dicantrarchus labrax), sea bream (Sparus aurata) analyzed by ICP-MS. Food Chem., 102: 721-725.

Harrocks, L.A. and Y.K. Yeo, 1999. Health benefits of Docosahexaenoic Acid (DHA). Pharmacol. Res., 40: $211-225$

Hossain, M.S., M. Hashimoto, S. Gamoh and S. Masumura, 1999. A anitoxidative effects of docosahexaenoic acid in the cerebrum versus cerebellum and brainstem of aged hypercholesterolemic rats. J. Neurochem., 72: 1133-1138.
Hultin, H.O. and S.D. Kelleher, 2000. Surimi Processing from Dark Muscle Fish. In: Surimi and Surimi Seafood, Park, J.W. (Ed.). Marcel Dekker Inc., New York, pp: 59-77.

Jang, J.R., H.J. Choi, K.K. Kim and S.Y. Lim, 2008. Effect of extracts from dried mackerel on antioxidant activity and inhibition of growth of human cancer cell lines. J. Life Sci., 18: 680-685.

Jang, J.R., K.K. Kim, S.B. Moon and S.Y. Lim, 2009. In vitro anticancer and antioxidant effect of solvent extracts from tuna dried at low temperature vacuum. J. Life Sci., 19: 633-638.

KSFSN, 2000. Handbook of Experiments in Food Science and Nutrition. Hyoil Press, Seoul, pp: 96-128.

Kanoh, S., T. Suzuki, K. Maeyama, T. Takewa, S. Watabe and K. Hashimoto, 1986. Comparative studies on ordinary and dark muscles of tuna fish. Bull. Jap. Soc. Sci. Fish, 52: 1807-1816.

Karthigayan, S., M.S. Balasubashini, M. Sengottuvelan, T. Balasubramanian and S.T. Somasundaram, 2006. Anticancer principles from salivary gland extract of Octopus ageina. Int. J. Cancer Res., 2: 242-252.

Kelleher, S.D., H.O. Hultin and K.A. Wilhelm, 1994. Stability of mackerel surimi prepared under lipidstabilizing processing conditions. J. Food Sci., 59: 269-271.

Khair-El-Din, T., S.C. Sicher, M.A. Vazquez, G.W. Chung and K.A. Stallworth et al., 1996. Transcription of the murine iNOS gene is inhibites by docosahexaenoic acid, a major constituent of fetal and neonatal sera as well as fish oils. J. Exp. Med., 183: 1241-1246.

Kitts, D.D., M.D. Huynh, C. Hu and A.W. Trites, 2004. Season variation in nutrient composition of Alaskan walleye Pollock. Can. J. Zool., 82: 1408-1415.

Komatsu, W., K. Ishihara, M. Murata, H. Saito and K. Shinohara, 2003. Docosahexaenoic acid suppresses nitric oxide production and inducible nitric oxide synthase expression in interferon- $\gamma$ plus lipopolysaccharide-stimulated murine macrophages by inhibiting the oxidative stress. Free Radical Biol. Med., 34: 1006-1016.

LeBel, C.P., H. Ischiropoulos and S.C. Bondy, 1992. Evaluation of the probe $2^{\prime}, 7^{\prime}$ dichlorofluorescin as an indicator of reactive oxygen species formation and oxidative stress. Chem. Res. Toxicol., 5: 227-231.

Lu, C.Y., J.G. Penfield, T.A. Khair-El-Din, S.C. Sicher, M.L. Kielar, M.A. Vazquez and L. Che, 1998. Docosahexaenoic acid, a constituent of fetal and neonatal serum, inhibits nitric oxide production by murine macrophages stimulated by IFN $\gamma$ plus LPS, or by IFNץ plus Listeria monocytogenes. J. Reprod. Immunol., 38: 31-53. 
Luzia, L.A., G.R. Sampaio, C.M.N. Castellucci and E.A.F.S. Torres, 2003. The influence of season on the lipid profiles of five commercially important species of Brazilian fish. Food Chem., 83: 93-97.

MIFAFF, 2009. Agricultural and Forestry Statistical Yearbook. MIFAFF Press, Seoul.

MacMicking, J., Q.W. Xie and C. Nathan, 1997. Nitric oxide and macrophage function. Annu. Rev immunol., 15: 323-350.

Mohan, M., D. Ramachandran, T.V. Sankar and R. Anandan, 2008. Physicolchemical characterization of muscle proteins from different regions of mackerel (Rastrelliger kanagurta). Food Chem., 106: 451-457.

Mordan, L.J., T.S. Burnett, L.X. Zhang, J. Tom and R.V. Cooney, 1993. Inhibitors of endogenous nitrogen oxide formation block the promotion of neoplastic transformation in $\mathrm{C} 3 \mathrm{H} 10 \mathrm{~T} 1 / 2$ fibroblasts. Carcinogenesis, 14: 1555-1559.

NFRDI, 2009. Chemical Composition of Marine Products in Korea 2009. NFRDI Press, Busan.

Nakada, M., 2008. Capture-Based Aquaculture of Yellowtail. In: Capture-based Aquaculture: Global Overview, Lovatelli, A. and P.F. Holthus (Eds.). FAO Press, Rome.

Nordov, A., R. Marchioli, H. Arnesen and J. Videbaek, 2001. N-3 polyunsaturated fatty acids and cardiovascular diseases. Lipids, 36: S127-S1 29.

Ochiai, Y., L. Ochiai, K. Hashimoto and S. Watabe, 2001. Quantitative estimation of dark muscle content in the mackerel meat paste and its products using antisera against myosin light chains. J. Food Sci., 66: 1301-1305.

Ohata, T., K. Fukuda, M. Takahashi, T. Sugiura and K. Wakabayashi, 1997. Suppression of nitric oxide production in lipopolysaccharide-stimulated macrophage cells by $\omega 3$ polyunsaturated fatty acids. Jap. J. Cancer Res., 88: 234-237.

Ohshima, H. and H. Bartsch, 1994. Chronic infections and inflammatory processes as cancer risk factors: Possible role of nitric oxide in carcinogenesis. Mutat. Res., 305: 253-264.

Salem, N., M. Reyzer and J. Karanian, 1996. Losses of arachidonic acid in rat liver after alcohol inhalation. Lipids, 31: 153-156.

Shahidi, F. and S.A. Spurvy, 1996. Oxidative stability of fresh and heat-processed dark and light muscles of mackerel (Scomber scombrus). J. Food Lipids, 3: $13-25$.
Sohn, J.H. and T. Ohshima, 2010. Control of lipid oxidation and meat color deterioration in skipjack tuna muscle during ice storage. Fish. Sci., 76: 703-710.

Sohn, J.H., Y. Taki, H. Ushio, T. Kohata, I. Shioya and $\mathrm{T}$. Ohshima, 2005. Lipid oxidations in ordinary and dark muscles off fish: Influences on rancid offodor development and color darkening of yellowtail flesh during ice storage. J. Food Sci., 70: 490-496.

Suzuki, H., S.J. Park, M. Tamura and S. Ando, 1998. Effect of the long-term feeding of dietary lipids on the learning ability, fatty acid composition of brain stem phospholipids and synaptic membrane fluidity in adult mice: A comparison of sardine oil diet with palm oil diet. Mech. Ageing Dev., 101: 119-128.

Tanakol, R., Z. Yazici, E. Sener and E. Sencer, 1999. Fatty acid composition of 19 species of fish from the Black Sea and Marmara Sea. Lipids, 34: 291-297.

Testi, S., A. Bonaldo, P.P. Gatta and A. Badiani, 2006. Nutritional traits of dorsal and ventral fillets from three farmed fish species. Food Chem., 98: 104-111.

Thakur, D.P., K. Morioka, Y. Itoh and A. Obatake, 2002. Influence of muscle biochemical constituents on the meat texture of cultured yellowtail (Seriola quinqueradiata) at different anatomical locations. J. Sci. Food Agric., 82: 1541-1550.

Thakur, D.P., K. Morioka, Y. Itoh and A. Obatake, 2003. Lipid composition and deposition of cultured yellowtail Seriola quinqueradiata muscle at different anatomical locations in relation to meat texture. Fish. Sci., 69: 487-494.

Tsukamoto, K., 1984. The role of the red and white muscles during swimming of yellowtail. Nippon Suisan Gakk, 50: 2025-2030.

Undeland, I., B. Ekstrand and H. Linggnert, 1998. Lipid oxidation in herring (Chpea harengus) light muscle, dark muscle and skin, stored separately or as intact fillets. J. Am. Oil Chem. Soc., 75: 581-590.

Yonekubo, A., S. Honda, M. Okano, K. Takahashi and Y. Yamamoto, 1994. Effects of dietary fish oil during the fetal and postnatal periods on the learning ability of postnatal rats. Biosci. Biotechnol. Biochem., 58: 799-801.

Zlatanos, S. and K. Laskaridis, 2007. Seasonal variation in the fatty acid composition of three Mediterranean fish-sardine (Sardina pilchardus), anchovy (Engraulis encrasicholus) and picarel (Spicara smaris). Food Chem., 103: 725-728. 